\section{References}

1. Oeppen R, Davidson M, Scrimgeour D, Rahimi S, Brennan P. Human factors awareness and recognition during multidisciplinary team meetings. J Oral Pathol Med 2019; 48: 656-661.

2. Davidson M, Brennan P. Leading article: What has an Airbus A380 Captain got to do with OMFS? Lessons from aviation to improve patient safety. Br J Oral Maxillofac Surg 2019; 57: 407-411.

3. Seager L, Smith D, Patel A, Brunt H, Brennan P. Applying aviation factors to oral and maxillofacial surgery - the human element. Br I Oral Maxillofac Surg 2013; 51: 8-13.

4. Kao L, Thomas E. Navigating Towards Improved Surgical Safety Using Aviation-Based Strategies. J Surg Res 2008; 145: 327-335

5. Aerden D, Smets D, Poelaert J, Oste J, Brande P. Fighting Human Error: What Surgeons Can Learn from Aviators. Acta Chir Belg 2014; 114: 228-232.

6. Gore D, Powell J, Baer J et al. Crew Resource Management Improved Perception of Patient Safety in the Operating Room. Am J Med Qual 2009; 25: 60-63.

7. de Korne D, van Wijngaarden J, Hiddema U, Bleeker F, Pronovost P, Klazinga N. Diffusing Aviation Innovation in a Hospital in the Netherlands. Jt Comm J Qual Patien Saf 2010; 36: 339-347.

8. Dow I. Simulation in flight safety - what can we learn from the airline industry? Acta Ophthalmol 2017; DOI: 10.1111/j.1755-3768.2017.02621.

9. Broom M, Capek A, Carachi P, Akeroyd M, Hilditch G. Critical phase distractions in anaesthesia and the sterile cockpit concept. Anaesthesia 2011; 66: 175-179.

10. Assael L. "Sully" Sullenberger and the Miracle on the Hudson: A Lesson in Heroism for Oral and Maxillofacial Surgeons. J Oral Maxillofac Surg 2009; 67: 711-712.

11. Ministry of Defence and Military Aviation Authority. Regulatory Article (RA) 2000 series: flying regulations (FLY). 2014. Available online at https:// www.gov.uk/government/publications/regulatoryarticle-ra-2000-series-flying-regulations-fly (accessed February 2020).

12. Health and Safety Executive. Provision and Use of Work Equipment Regulations 1998 (PUWER) - Work equipment and machinery [Internet]. Hse.gov.uk. [cited 3 February 2020]. Available from: https://www.hse.gov. uk/work-equipment-machinery/puwer.htm.

13. Lifting Operations and Lifting Equipment Regulations 1998 (LOLER) - Work equipment and machinery. Available at https://www.hse.gov.uk/work-equipmentmachinery/loler.htm (accessed February 2020).

14. Medicine \& Healthcare products Regulatory Agency. Managing Medical Devices: Guidance for health and social care organisations. 2015. Available at https:// assets.publishing.service.gov.uk/government/uploads/ system/uploads/attachment_data/file/421028/ Managing_medical_devices_-_Apr_2015.pdf (accessed April 2020)

15. Health and Safety Executive. Hand arm vibration - Key messages. Available at https://www.hse.gov.uk/vibration/ hav/keymessages.htm (accessed February 2020).

16. BMJ Best Practice. Raynaud's phenomenon Symptoms, diagnosis and treatment. Available online at https://bestpractice.bmj.com/topics/en-gb/193/ aetiology (accessed May 2020).

17. Kierklo A, Kobus A, Jaworska M, Botuliński B. Workrelated musculoskeletal disorders among dentists - a questionnaire survey. Ann Agric Environ Med 2011; 18: $79-84$
18. Hayes M, Cockrell D, Smith D. A systematic review of musculoskeletal disorders among dental professionals. Int J Dent Hyg 2009; 7: 159-165.

19. Brown J, Burke F, Macdonald E et al. Dental practitioners and ill health retirement: causes, outcomes and re-employment. Br Dent J 2010; 209: E7.

20. Dentists' Provident. 2019 claims statistics. 2020. Available at https://www.dentistsprovident.co.uk/ media/1514/claims-stats-2019.pdf (accessed April 2020)

21. World Health Organisation. WHO Surgical Safety Checklist. 2009. Available online at https://www.who. int/patientsafety/safesurgery/checklist/en/ (accessed April 2020).

22. Ludders J, McMillan M. Errors in veterinary anaesthesia. 1st ed. Ames: Wiley Blackwell, 2017.

23. Boorman D J, Higgins W Y. Checklists to Enhance Safety. 2016. Available at https://www.boeing.com/features/ innovation-quarterly/2019_q3/btj-checklist.page (accessed May 2020).

24. NHS Improvement. The future of the patient safety incident reporting: upgrading the NRLS. 2020. Available online at https://improvement.nhs.uk/news-alerts/ development-patient-safety-incident-managementsystem-dpsims/ (accessed May 2020)

25. Blenkinsopp J, Snowden N, Mannion R et al. Whistleblowing over patient safety and care quality: a review of the literature. J Health Organ Manag 2019; 33: 737-756.

26. Reason J. Human error: models and management. $B M$ 2000; DOI: $10.1136 / \mathrm{bmj} .320 .7237 .768$.

27. Air Accidents Investigation Branch. 1/1992 BAC OneEleven, G-BJRT, 10 June 1990. 2014. Available online at https://www.gov.uk/aaib-reports/1-1992-bacone-eleven-g-bjrt-10-june-1990 (accessed December 2019).

28. World Health Organisation. Burn-out an "occupational phenomenon": International Classification of Diseases. 2019. Available at https:// www.who.int/mental_health/evidence/burn-out/ en/ (accessed April 2020)

29. Anonymous. More than half of dentists say stress is affecting their practice. Br Dent J 2019; 226: 7 .

30. Basson R A. Management and Prevention of Burnout in the Dental Practitioner. 2013. Available at https:// www.longdom.org/open-access/managementand-prevention-of-burnout-in-the-dentalpractitioner-2161-1122.1000168.pdf (accessed May 2021)

31. Lee R, Ashforth B. A meta-analytic examination of the correlates of the three dimensions of job burnout. J Appl Psychol 1996; 81: 123-133.

32. Demerouti E, Veldhuis W, Coombes C, Hunter R. Burnout among pilots: psychosocial factors related to happiness and performance at simulator training. Ergonomics 2018; 62: 233-245.

33. Bakker A B, Demerouti E, Sanz-Vergel A I. Burnout and Work Engagement: The JD-R Approach. Ann Rev Organ Psychol Organ Behav 2014; 1: 389-411.

34. Transport Committee, House of Commons. The impact of the coronavirus pandemic on the aviation sector. 2020. Available at https://publications.parliament. uk/pa/cm5801/cmselect/cmtrans268/26807 htm\#footnote-150 (accessed August 2020).

35. Smithsonian Channel. Cultural Norms Cloud Cockpit Communications. 2013. Available at https://www. youtube.com/watch?v=aG3_nJYtrO8\&t=5s (accessed May 2020).
36. British Medical Association. Terms and Conditions of Service for NHS Doctors and Dentists in Training. 2016. Available online at https://www.bma.org.uk/pay-andcontracts/contracts/junior-doctor-contract/juniordoctor-contract-in-england (accessed May 2020).

37. British Medical Association. Exception reporting for junio doctors. 2020. Available at https://www.bma.org.uk/payand-contracts/working-hours/work-schedule/exceptionreporting-for-junior-doctors (accessed June 2020).

38. Arnold J. Staff goodwill is a critical lifeline for the survival of the NHS. 2019. Available at https://www.hsj.co.uk/ workforce/staff-goodwill-is-a-critical-lifeline-for-thesurvival-of-the-nhs/7025811.article (accessed May 2020)

39. Pickersgill T. The European working time directive for doctors in training. BMJ 2001; DOI: 10.1136/ bmj.323.7324.1266.

40. NHS. Pay for dentists. Available at https://www. healthcareers.nhs.uk/explore-roles/dental-team/rolesdental-team/dentist/pay-dentists (accessed August 2020).

41. UK Government. Ms M Gorman v Terence Paul (Manchester) Ltd. 2020. Available at https://assets.publishing.service.gov.uk/ media/5f2194eed3bf7f1b13f64f69/Ms_M_ Gorman v Terence Paul Manchester Limited_-_2410722_2019.pdf (accessed August 2020).

42. Dungarwalla M, Chapireau D, Bentley R. Use of WhatsApp in an oral and maxillofacial surgery department at a major trauma centre and its role during major incidents: our experience. Br J Oral Maxillofac Surg 2019: 57: 449-453.

43. Cho $\mathrm{S}$, Lee E. Distraction by smartphone use during clinical practice and opinions about smartphone restriction policies: A cross-sectional descriptive study of nursing students. Nurse Educ Today 2016; 40: 128-133.

44. Nursing Times Contributor. The effectiveness of drug round tabards in reducing incidence of medication errors. 2010. Available at https://www.nursingtimes. net/archive/the-effectiveness-of-drug-roundtabards-in-reducing-incidence-of-medicationerrors-30-08-2010/ (accessed May 2020).

45. Black Box Dentistry. Homepage. 2020. Available at http:// www.blackboxdentistry.co.uk/ (accessed January 2020).

46. HSL. Behaviour Change: Achieving Health \& Safety Culture Excellence. Available at https://www.hsl.gov. uk/health-and-safety-training-courses/behaviourchange-achieving-health-safety-culture-excellence (accessed May 2020)

47. Mannion R, Davies H. Understanding organisational culture for healthcare quality improvement. BMJ 2018; DOI: $10.1136 / \mathrm{bmj} . \mathrm{k} 4907$

48. The King's Fund. NHS leadership and culture: our position. 2020. Available at https://www.kingsfund. org.uk/projects/positions/NHS-leadership-culture (accessed May 2020).

49. Jacobs R, Mannion R, Davies H, Harrison S, Konteh F, Walshe $K$. The relationship between organisational culture and performance in acute hospitals. Soc Sci Med 2013: 76: 115-125.

50. Mannion R, Davies H T, Marshall M N. Cultural characteristics of "high" and "low" performing hospitals. $J$ Health Organ Manag 2005; 19: 431-439.

51. Scott T, Mannion R, Davies H T, Marshall M N Implementing culture change in health care: theory and practice. Int J Qual Health Care 2003; 15: 111-118.

52. Verbakel $\mathrm{N} J$, de Bont A A, Verheii T J, Wagner C, Zwart $D \mathrm{~L}$. Improving patient safety culture in general practice: an interview study. Br J Gen Pract 2015; DOI: 10.3399/ bjgp15X687865.

\title{
Correction to: Book review: Dental interviews (1st edition) - A comprehensive guide to DCT \& ST interview skills
}

The original article can be found online at https://doi.org/10.1038/s41415-021-3027-7.

Author's correction note:

Book review article Br Dent J 2021; 230: 570 .

When this article was initially published the author's name was spelt incorrectly as 'Kirsty Cowen'. The author's name is spelt Kirsty Cowan.

The journal apologises for any inconvenience caused. 